\title{
Genetic information: Important but not "exceptional"
}

\author{
Ruth Hannah Wilkinson
}

Received: 1 March 2010 / Accepted: 16 July 2010 /Published online: 31 July 2010

(C) The Author(s) 2010. This article is published with open access at Springerlink.com

\begin{abstract}
Much legislation dealing with the uses of genetic information could be criticised for exceptionalising genetic information over other types of information personal to the individual. This paper contends that genetic exceptionalism clouds the issues, and precludes any real debate about the appropriate uses of genetic information. An alternative to "genetically exceptionalist" legislation is to "legislate for fairness". This paper explores the "legislating for fairness" approach, and concludes that it demonstrates a fundamental misunderstanding of both how legislation is drafted, and how it is interpreted. The uncomfortable conclusion is this: policy-makers and legislators must tackle head-on the difficult policy questions concerning what should and should not be done with genetic information. Only by confronting this crucial issue will they achieve a workable legislative solution to the problems caused by genetic information.
\end{abstract}

Keywords Genetic information · Genetic exceptionalism · Insurance · Legislation · Law $\cdot$ Ethics

\section{Introduction}

Deciding on the appropriate uses of predictive genetic information is proving to be a significant challenge for those responsible for legislating in this area. There is little disagreement about the value of knowing about genetic predispositions for the purposes of medicine and healthcare-for example, knowing that you have the BRCA gene, indicating a predisposition to breast cancer, means that you can benefit from risk-reducing surgery and closer monitoring of your health. However, there is much less agreement about whether an insurance company should have access to

R. H. Wilkinson $(\bowtie)$

Sussex Law School, School of Law, Politics and Sociology, University of Sussex, Friston Building,

Falmer, East Sussex BN1 9SP, UK

e-mail: ruth.wilkinson@sussex.ac.uk

URL: http://www.sussex.ac.uk/law/profile243525.html 
that information. Ashcroft (2007) and Holm (2007) outline the difficult issues which arise. On one hand, insurers argue that knowing this type of information means that premiums can be set more accurately than would be possible if that information was not available (Smith and Raithatha 2006). It is also conceivable that insurers would "reward" risk-reducing behaviour by a decrease in premiums (Davey 2000). Having access to this information allows the insurance industry to remain flexible, and to ensure that insurers are not caught out by large claims which have not been paid for through the premiums. If insurers are caught out too many times, they argue that the industry will collapse (Meyer 1993).

On the other side is the argument that this treatment is unfair to those with genetic risks. It is unfair to deny them access to something as important as life insurance on the basis of a genetic predisposition, over which they have no control (Moultrie and Thomas 1997). As well as this being bad for the individual who may have no financial protection, this could also have a significant impact on their family members whose risks are also affected by this information. It is one thing to increase insurance premiums because of the results of the applicant's genetic test. It is another thing entirely to increase the applicant's premiums on the basis of the results of their family's genetic tests. There is an assumption that familial genetic test results are relevant to the individual applicant, however, it is not clear that this will always be the case. Further, even if we can show that they are relevant, it does not necessarily follow that it is appropriate to use them as the basis of an insurance decision. ${ }^{1}$ Furthermore, even if it was considered to be appropriate to use predictive genetic test information, there is huge variation in the implications of having a genetic predisposition. In some cases, the gene is of such high penetrance, that having the predisposition is tantamount to a certainty. It is almost guaranteed that the condition will eventuate. The majority of genetic predispositions do not attract this degree of certainty, and only show that an individual has a slightly elevated risk of suffering from the condition in question (Macdonald 2004). It is far from clear that there is a good understanding of what this risk means, and therefore, far from clear that this type of risk should be considered in insurance decisions. On a more general level, this sets a precedent for stratifying society on the basis of genetic make-up. We have seen from history how negative it was to divide society on grounds of race, and it is difficult to see how it is justifiable to do something similar with genetic make-up. Given these polar opposite views, it should be apparent why legislators and policymakers are finding it challenging to decide how our predictive genetic information should be used.

The difficulties associated with these decisions are brought into sharp relief by insurance. The problem in the insurance context is that the arguments are very finely balanced. If we accept that the actuarial process is the most appropriate basis for insurance then it is difficult to argue that insurers should ignore relevant information such as predictive genetic test results. But, the actuarial process could lead to significant numbers of people being refused life insurance cover directly, or

\footnotetext{
${ }^{1}$ It might be argued that race or ethnicity is relevant to the decision whether to offer life insurance, and that therefore insurers should be able to make decisions on the basis of race. However, in the UK for example, this is prohibited by the Race Relations Act 1976. A state may decide that relevant characteristics cannot be used in insurance decisions.
} 
indirectly as a result of very high premiums. Inability to access insurance can be associated with other forms of significant financial exclusion, particularly difficulties with obtaining a mortgage or repaying a mortgage once obtained. Further, individuals and families might be forced to rely on savings in the absence of insurance, which leaves them vulnerable to financial crisis (Mitton 2008). We can also argue that it is unfair for reasons to do with social justice to exclude people from life insurance cover on the basis of something, such as genetic make-up, over which they have no control.

A number of states have attempted to offer a solution to this issue. In the UK, the insurance industry and the government have agreed a temporary voluntary moratorium on the use of predictive genetic test results for insurance purposes. The moratorium is renewed every 3-5 years, and is due to expire in 2014. In Belgium, there is legislation which prohibits the use of genetic information for insurance purposes. Similar prohibitions of the use of genetic information for insurance purposes were included in the Irish Disability Discrimination Act 2005. Recently, the Genetic Information Nondiscrimination Act 2008 came into force in the US. This Act prohibits the use of genetic information in employment and health insurance decisions. All the Acts take a similar approach. At the core is a definition of genetic information which the prohibitions are constructed around. If the information in question meets the standard laid down in the definition then it will be prohibited to use it in particular ways. Violating the law leads to some remedy being awarded to the sufferer.

There is no doubt that it was difficult for the relevant policy-makers and legislators to choose the most appropriate way to deal with the problems caused by the use of genetic information. It is a controversial issue, about which are there are many differing views. However, the wisdom of all of these approaches can be criticised on the basis that they exceptionalise genetic information. This is potentially very damaging to society in that it may legitimise the stratification of society along genetic lines. There is a real question about why this genetically exceptionalist legislative approach has been chosen. In this paper, I explore what genetic exceptionalism is. I then go on to look at the approaches chosen in the UK and the US, and discuss the problems arising from the genetic exceptionalist stance. Finally, I argue that, notwithstanding the problems caused by genetic exceptionalism, the alternative suggestion of "legislating for fairness" is unworkable and incoherent. For this reason, legislators must tackle head-on the question of how our predictive genetic information should be used.

\section{What is genetic exceptionalism?}

"Genetic exceptionalism" is the notion that there is something special about genetics which makes it legitimate to treat genetic information differently to other types of information for the purposes of regulation. Invariably, differently means better. Whatever it is that makes genetic information special, can justify a much higher level of legislative or political protection than would be available for non-genetic information. The question then, is what is special about genetic information?

There are a number of different approaches taken to this question, and predictably, there is little agreement between the analysts. Sarata (2008 p 1) argues that genetic 
information has a number of characteristics which make it different from other types of medical information:

it can be predictive of future disease; it is a unique identifier; it can reveal information about family members; it is vertically transmitted (passed from parent to child); it can impact communities; it can be used to discriminate and stigmatize; and it can cause serious psychological harm. In addition, although not specific to genetic information, the following characteristics also describe genetic information: it can be obtained from small samples (possibly without consent); it may be used for purposes other than those for which it was collected; it is of interest to third parties (such as employers and insurers); it may be important for determining susceptibility to disease and effectiveness of treatment; and it can be recovered from stored specimens after many years.

She argues that it is the combination of these characteristics that make genetic information different to other information, and more importantly, more special than other types of information. Taken individually, some of these characteristics are apparent in various other types of information relevant to each of us. For example, my name, date and time of birth could amount to a 'unique identifier' of me. Knowledge of an HIV + status, or infertility may cause me to suffer 'serious psychological harm'. Whilst it would be facetious to dismiss each of the characteristics in this way, it could be done. Her argument is then, that the total specialness of genetic information is greater than the sum of its individual characteristics. There is something extra about genetic information which makes it more special than other information. Green and Botkin (2003), who ultimately conclude that there is nothing special about genetic information, take a similar approach to Sarata (2008). They consider four characteristics of genetic information which are said to distinguish it from other types of medical information. They discuss claims that genetic information is special because it can predict the future, it provides information about family members as well as the individual being tested, it has been used to discriminate against and to stigmatise people and finally that serious psychological harm might be caused to individuals and families through knowledge from genetic information. Each of these claims for the specialness of genetic information is dismissed on the grounds that they do not only apply to genetic information. If we are to find that genetic information is special on the basis of these characteristics, then we must also find that other information with the same characteristics is as special as genetic information. Green and Botkin's (2003) argument is that the total specialness is equal to the sum of the individual characteristics, and since those do not indicate that there is anything special about genetic information, the combination will not either.

If its characteristics are not sufficient to show that there is something special about genetic information, then there must be some other explanation for genetic exceptionalism. Green and Botkin (2003 p 572) highlight a possible argument: 'Right or wrong, genetic information is believed to reveal who we "really" are'. They do not tackle this argument, simply accepting that this view might be held. However, this argument might unlock why there is such strong feeling about the importance of genetic information, and why authors such as Sarata (2008) feel able to argue that genetic information is special despite there being nothing in the characteristics of genetic information to support that claim. 
Richards (2001 p 667) explores the argument in more depth. He begins with a particularly eloquent quote from Bill Clinton who suggested that 'genes are "the language in which God created man"'. This he tackles from two angles, first the biology, and then the social construction of DNA. The two angles begin from the same point: our genes are us. If our genes are the essence of our humanity, then our genetic information deserves special treatment because our humanity deserves respect. Genetic information becomes something mystical and spiritual. This mystical nature is drawn to the forefront, and used as a trump card to end discussions about the importance of genetics. If our genetic information is the core of our existence then there can be no doubt about the place of genetic information in society. It must be paramount. Richards (2001 p 668) challenges this position by considering the biology of genetics and argues that 'DNA may be a large and complex molecule, but alone it does nothing'. DNA is a small part of a much larger developmental process. Genes are a necessary, but not sufficient condition for existence.

It becomes clearer when he considers the social construction of DNA, why this biological reality seems to be overlooked. The main problem he identifies is that scientists' primary method of communication with the public is through metaphors. These metaphors tend to be deterministic and essentialist, identifying genetic information as the only developmental factor worth any salt (Richards 2001). Furthermore, many of these analogies tend to be with computer science or communication technology. If scientists refer to the human genome as a compact disc, then it is no small wonder that the wider population understand their genetic make-up to hold everything of the essence of them. This becomes a vicious circle. These types of metaphors are understood and accepted by the general public, so the scientific community continue to use them. Unfortunately, the compact disc analogy is unidirectional. Information can only flow from the genes, and never back to the genes (Richards 2001). This puts the genome on a pedestal, separating it from the developmental system which it could not function without.

This goes a long way to explaining why genetic information is seen as more important and more special than other information about us. The high esteem that genetic information is held in is more akin to a religious fervour. Often not explicitly, this attitude permeates discussions of the importance of genetic information. Those who believe that it is special may find it difficult to explain why, and will remain unconvinced by arguments refuting their views which are based on the characteristics of the information. The true believer will never be convinced by the committed atheist.

If this is the, unacknowledged, reason why genetic information is seen as more important than other information, then we have a problem. This attitude prevents a proper discussion being had of whether genetic information is special in some way. "Genetic" is used as a trump card, and discussion stops. Furthermore, if there are in fact good reasons for acting with caution in relation to the use of genetic information, then those good reasons are subsumed into the "genes are us" justifications for treating genetic information differently. Until we remove the religious overtones, there is no hope of coming to a sensible conclusion about whether there is anything special-exceptional-about genetic information which could justify differences in the legislative and political approaches to its protection.

Despite the difficulty of identifying why genetic information is special, some states have given legislative or quasi-legislative protection to genetic information, 
prohibiting its use for particular purposes or in particular ways. By singling out genetic information for special treatment, it can be argued that these approaches feed into the view that genetic information is special. Unfortunately, this does not appear to be a virtuous circle. It simply provides more reasons why we should treat genetic information differently, enhancing the mystical views of genetic information and adding more barriers to a discussion of whether there is anything special about genetic information.

There is a further difficulty with genetic exceptionalism, which may be an extension of the problems of mysticism. Singling out genetic information as the important factor in development of particular medical conditions endorses the view that genetic make-up is the sole cause of the condition. This view is known as genetic determinism, defined by Kirby (2000 p 197) as 'the belief that human behaviour, personality, and physical appearance are determined exclusively by a person's genetic makeup. Genetic determinism is a reductionist ideology in that it seeks to explain a complex whole (a human being) in terms of its component parts (individual genes)'. The problem with genetic determinism, as I have argued elsewhere (Wilkinson 2010) is that it does not reflect the biological reality that genes are only a small part of the reason we are who we are. Genetic exceptionalism and genetic determinism strengthen each other, and can be used to justify discrimination on the basis of genetics. If genes are the most important factor in who we are, then it is logical to conclude that the way we are is dictated by our genes. We can take this a step back and say that if an embryo is found to have the gene for laziness for example, then the child and adult it will become will be lazy. At the moment, if a child is found to be lazy, then parents and teachers would encourage a change in behaviour. In the genetically determined future, the child might be left to his or her laziness, justified by the idea that s/he was designed that way. Whilst this might be a frivolous example, it is not confined to this issue. It might be seen as acceptable to deny employment on the basis of a genetic predisposition, or to deny access to healthcare where there is a predisposition which might prevent treatment being successful. For example, if there is a genetic predisposition towards addiction, then it might be justifiable to deny addiction treatments to anyone with that predisposition. If we subscribe to and endorse genetic determinism then we have to agree that irrespective of our interventions, the genes will win. Whatever we do to help the genetically-predisposed drug addict will be a waste of time and resources since it cannot hope to succeed. If that is the case, then we are better off conserving our scarce resources and denying addiction treatment. While this is no doubt the antithesis of what we are more likely to think is appropriate - that we should be treating people with addiction problems - denial of treatment to those with a genetic predisposition is the logical future of a society that endorses genetic determinism.

It seems clear that there are some serious difficulties with the concept of genetic exceptionalism. It is arguable that legislative and quasi-legislative approaches which endorse this concept are flawed and could be harmful to the societies they are part of. The next section will explore the ways in which the UK and the US have approached the problem of the use of genetic information for insurance purposes, and consider whether the claim that these approaches endorse genetic exceptionalism has any truth. 


\section{Genetically exceptionalist legislation?}

In the UK, there has been a moratorium on the use of genetic test information for insurance purposes since 1998. It was introduced by the Association of British Insurers ("ABI") in response to concerns from the public and the media about discrimination. Davey (2000 p 588) notes that this first agreement 'did not rule out the use of existing genetic test results in assessing whether and on what terms to conclude contracts of insurance', although there would be no requirement for consumers to undergo predictive tests before applying for insurance. The industry's moratorium was initially intended to run for 3 years. When it came up for review in 2001, the House of Commons Science and Technology Committee strongly recommended that the government and the ABI should agree the continuation of the moratorium for at least two more years (Science and Technology Committee 2000-1 [71]). This strong recommendation was backed up by a suggestion that if insurers were 'unable, or unwilling, to regulate themselves' the government should 'enforce its will by legislation'. The ABI's response was to negotiate with the government for a continuation of the moratorium for 5 years (Daykin et al 2003 p 813). The 2001 moratorium was reviewed in 2005, and in March of that year the government and the ABI published their Concordat and Moratorium on Genetics and Insurance (Department of Health 2005). It was informed by discussions between the government, the ABI, the Genetics and Insurance Committee ("GAIC"), the Human Genetics Commission ("HGC"), patient groups and other interested parties, and was described as 'a single high-level policy agreement' that would establish 'a robust and flexible framework for cooperation between the government and the Association of British Insurers' (Department of Health $2005 \mathrm{p} \mathrm{1-2).} \mathrm{The}$ moratorium was due to expire on 1 November 2011 but its application was extended when the concordat was reviewed in 2008. The moratorium will now run until 2014 (Association of British Insurers 2008).

The moratorium (Department of Health 2005) itself is formed of two provisions:

1. Customers will not be required to disclose the results of predictive genetic tests for policies up to $£ 500,000$ of life insurance, or $£ 300,000$ for critical illness insurance, or paying annual benefits of $£ 30,000$ for income protection insurance ("the financial limits"). More than $97 \%$ of policies issued in 2004 were below these limits in each category.

2. When the cumulative value of insurance exceeds the financial limits, insurers may seek information about, and customers must disclose, tests approved by $\mathrm{GAIC}^{2}$ for use for a particular insurance product, subject to the restrictions in the Concordat.

To date, the only test approved by GAIC is for the predisposition towards Huntington's Chorea, and the ABI has no intention of applying for approval of any other genetic tests (Genetics and Insurance Committee undated). At this point in time,

\footnotetext{
${ }^{2}$ GAIC has recently been disbanded and the Human Genetics Commission has taken over its role.
} 
no one applying for life insurance, critical illness insurance or income protection insurance will be required to disclose the results of a predictive genetic test, unless they are applying for products which exceed the financial limits, in which case they will have to disclose the results of a Huntington's test, if they have had one. The concordat also states that predictive genetic test information will not be relevant to, and thus will not be used when pricing, travel insurance, private medical insurance, any one-off or annual policy or for long-term care policies. Whilst there are numerous arguments to be made about the effectiveness of the moratorium as an approach to dealing with this problem (Wilkinson 2010) it is apparent that this amounts to an almost blanket ban on the use of predictive genetic test results for insurance purposes. ${ }^{3}$

To a certain extent, it appears that the moratorium exceptionalises genetic information. There is no comparable policy for other types of medical information. The legal position is that insurance contracts are uberrimae fide $i$ - with utmost good faith-which means that there is a requirement for applicants to disclose all information that is material to the decision to offer insurance and setting premiums. ${ }^{4}$ Since the test for materiality is whether the information would have affected the insurer's judgment when deciding whether to offer insurance or set a premium, ${ }^{5}$ it will be necessary for an applicant to disclose most information. The moratorium excludes predictive genetic test results from the ordinary legal position, setting that type of information above other types of information which might still have a number of characteristics in common with predictive genetic information. In addition, the concordat specifically preserves insurers' rights to take account of family medical histories and medical reports when setting premiums and deciding whether to offer insurance at all (Department of Health 2005). In the majority of cases, an individual's family medical history will give insurers more than enough information to make an accurate prediction of an applicant's risk. If an applicant has a family history of a highly penetrant dominant single gene disorder such as Huntington's Chorea, then at the very least their premiums will be considerably higher than an applicant without such a family history, and they may also be denied

\footnotetext{
${ }^{3}$ It might be argued that the position in the UK has a lot to recommend it, since most people can access insurance without having to disclose the results of a predictive genetic test. However, the potential for injustice arises from the temporary nature of the moratorium. There is nothing stopping insurers deciding to depart from the moratorium. At best, the Association of British Insurers has moral authority over its members and cannot bind them to keep to the moratorium. Further, there is no guarantee that those who have had a test while the moratorium has been in force would be protected if the moratorium were not to be renewed. This "test now, buy later" problem is of such concern that there is anecdotal evidence that some physicians are still advising patients to buy all the insurance cover they need before undergoing a predictive genetic test (Human Genetics Commission undated). Thanks to Loane Skene for highlighting this issue.

${ }^{4}$ Bell v Lever Bros Ltd [1932] A C 161, 227; Banque Keyser SA v Skandia (UK) Ins Co Ltd [1990] 1 QB 665, 769. Carter v Boehm (1766) 3 Burr 1905, 1909-1910.

${ }^{5}$ The test for materiality is to be found in section 18(2) of the Marine Insurance Act 1906: 'Every circumstance is material which would influence the judgment of a prudent insurer in fixing the premium or determining whether he will take the risk.' It was confirmed that this test applies to all classes of insurance in Lambert v Cooperative Insurance Society [1975] 2 Lloyd's Rep 485 and Pan Atlantic Insurance Company v Pine Top Insurance Company Limited [1995] 1 AC 501.
} 
insurance cover altogether. ${ }^{6}$ The discrepancy in approach is even more obvious in this example: imagine that there is a predictive genetic test for heart disease. This genetic test has a very high degree of accuracy, and thus it is tantamount to a certainty. Two individuals apply for life insurance on the same day. The first applicant, Anna, has a family history of heart disease, smokes and is overweight. She has not had a genetic test for the predisposition to heart disease. The second applicant, Bertha, has a clean family history, is a lifelong non-smoker, and is a healthy weight. She has undergone the genetic test for heart disease and is positive for the predisposition. Assume that the risks shown by Anna's family history are comparable to the risks shown by Bertha's genetic test information. Both Anna and Bertha have the same risk of suffering from heart disease. Under the current position in the UK, Anna would be required to disclose her family medical history and her smoking habit, and her life insurance premiums would be adjusted upwards to compensate. Bertha would disclose her clean family medical history, her lack of smoking habit, and her premiums would be lower than average. She would not be required to disclose her predisposition. Although Anna and Bertha have identical risk factors, Bertha would end up paying a significantly lower premium than Anna. On the face of it, Anna and Bertha are identical, but Bertha is protected by a genetically exceptionalist moratorium, where Anna has to take full responsibility for her risk. Both women will suffer from the same condition and in the same way. The only reason that they are treated differently by the law is Bertha's good fortune to have had the test for a genetic predisposition to heart disease and Anna's bad luck not to. There is no other reason for treating these two cases differently, and yet the law does so because of the genetic factor. It considers the genetic make-up to be a good reason for distinguishing the cases. This seems to be genetic exceptionalism at its purest.

The approach taken in the US is different from that taken in the UK. There is federal legislation which prohibits genetic discrimination in health insurance and employment. The Genetic Information Nondiscrimination Act 2008 ("GINA") came into force in May 2009 (Anonymous 2008; Murphy 2009) after a thirteen year battle to get it onto the statute book. Hudson et al. (2008) note that the first federal legislation to prohibit the misuse of genetic information was introduced in 1995. At the time, they argue, researchers and scientists in the area thought that this law was forward-looking. It was showing a strong commitment to the protection of its citizens for the US to introduce legislation to protect them against genetic discrimination when there were very few genetic tests available. Fourteen years later, the Act has come into force, and the climate has changed significantly. To illustrate, in 2001, a case was brought by the Equal Employment Opportunity

\footnotetext{
${ }^{6}$ There is a real question about whether the use of family history information is appropriate in insurance decisions, since it can result in an applicant and their family becoming uninsurable. This already happens to families with a history of Huntington's Chorea. This question must fall outside the scope of this article, however, there is no doubt that it needs further exploration. In the UK at the moment, it is lawful for insurers to use family history information to underwrite life insurance. The discussion of genetic test information in this article is designed to highlight the discrepancies in allowing the use of family history information and not allowing the use of predictive genetic test information. Arguments that insurers should not be able to use family history information force the proponent to argue for a fundamental change to the nature of insurance. This argument is worth having, but it cannot be given full consideration in this paper. Thanks to Loane Skene for highlighting this issue.
} 
Commission ("EEOC") against the Burlington Northern Santa Fe Railway Company ("BNSF") for disability discrimination. In that case, ${ }^{7}$ BNSF were challenged on the basis that their compulsory medical examination contained a genetic test for a predisposition to carpal tunnel syndrome. Carpal tunnel syndrome had affected a number of BNSF employees and the argument was made that having this information in advance would enable the company to resolve claims for compensation in a more timely manner. Whilst, on the face of it, this justification seems to be harmless, it has wider implications. If this test had shown that particular employees had a predisposition towards carpal tunnel syndrome then it would have been legitimate for the company to lower the compensation offered should those employees suffer from the condition at any stage in their employment. If this policy had been allowed to continue, then we have a similar situation to that of Anna and Bertha. Imagine that Clyde and Denton both work for BNSF. After 20 years of employment, they have both developed carpal tunnel syndrome. Clyde has no predisposition, and the condition is found to have been caused by his employment activities. In his medical examination, Denton was found to have the genetic marker for carpal tunnel syndrome. His condition is found to have been caused jointly by his predisposition and his employment activities. On a strict proportion calculation, Denton would be entitled to half the compensation that Clyde was offered. The only difference between their cases is that Denton has a genetic predisposition where Clyde does not. Denton has the same loss of functionality as Clyde, and the same pain levels, but is penalised for something over which he has no control. Fink (2003 $\mathrm{p}$ 528) argues that the only reason the EEOC challenged BNSF was because the carpal tunnel test was a genetic test. The 33 other tests that were carried out were found not to violate their duties under the Americans with Disabilities Act 2002. If the other tests were able to provide sufficient information for BNSF to predict which employees would suffer from carpal tunnel syndrome, then it is certainly arguable that the only reason for challenging the genetic test was because there is something special about genetic information. Genetic information is exceptionalised in an attempt to protect employees.

This case indicated the direction in which the legislature would be going in relation to the use of genetic information. In the US, unlike in the UK, there is no National Health Service, and the majority of health insurance, and thus healthcare, is provided through employers. Since employers will pay health insurance premiums for their employees, it could be argued that if genetic information would have a significant impact on the cost of those health insurance premiums, employers should have access to that information. Counterbalancing this, is the serious concern that employers might use this type of information to deny employment to those with genetic predispositions to serious conditions. The Genetic Information Nondiscrimination Act 2008 sought to allay those concerns. GINA prohibits the use of genetic information for restricting access to health insurance ${ }^{8}$ and employment discrimination on the basis of genetic information. ${ }^{9}$ Health insurers are prohibited from adjusting insurance

\footnotetext{
7 The case was unreported, but Stephen Fink's article (Fink 2003) is extremely enlightening.

${ }^{8}$ Sections 101-106.

${ }^{9}$ Sections 201-213.
} 
premiums on the basis of genetic information, and from requesting, requiring or collecting genetic information for underwriting purposes. With regards to employment, employers may not decide whether or not to employ someone, or whether or not to retain an employee's services on the basis of information about their genetic make-up. Nor may an employer deny employment opportunities on the basis of genetic information. ${ }^{10}$

This legislation is intended to target an area of growing concern. Matloff et al's (2000) study of genetic counsellors showed that fear of insurance repercussions could lead to patients choosing not to have tests that they otherwise would want, and taking genetic tests under assumed names in order to keep the information away from their health insurer. Notwithstanding that there may be very good reasons for enacting legislation of this sort, there is no doubt that it also exceptionalises genetic information. The position highlighted by the BNSF case supports this conclusion. Even prior to the enactment of GINA, employers could be challenged for using genetic tests but not for using other medical tests, even where those medical tests provided the same amount of information as a genetic test. GINA continues this position. A health insurer can be legally challenged if it changes premiums on the basis of genetic information but not where changes to premiums are justified on other grounds.

This comparison of the UK and the US, albeit brief, leads us to an unfortunate conclusion: all legislative or quasi-legislative approaches which prohibit discrimination on the grounds of genetic make-up could be subject to the genetic exceptionalism criticism. Further, if genetic exceptionalism is as harmful as it is suggested, then it would seem logical to argue that legislative or quasi-legislative approaches grounded in genetic exceptionalism are as harmful, and should not be part of our portfolio of solutions. This claim was made by Ron Zimmern at a recent seminar organised by the Human Genetics Commission. ${ }^{11}$ Essentially, he argued that there was no relevant difference between genetic information and other information. He argued that since this was the case, we should not be trying to solve the problem of "genetic" discrimination. The implication was that we should look at discrimination in a general way rather than narrowing it down into specific categories. One might call this a "legislating for fairness" claim. Whilst this position is intuitively attractive to the non-lawyer, it is not as straightforward as it might seem.

\section{Could we legislate for fairness?}

Once we move into the realms of legislation and law-making, it is imperative that the provisions written are usable in day-to-day life. Diver (1983) argues that, in order to be administratively workable, rules must be transparent, accessible and congruent. A

\footnotetext{
${ }^{10}$ The first cases are already being brought under GINA. In one case, Pamela Fink alleges that the company she worked for, MXenergy, terminated her employment because she tested positive for the BRCA gene, and had some time off work for a mastectomy. The company deny the allegations (Lowe 2010).

${ }^{11}$ Papers from Understanding Genetic Discrimination are available at www.hgc.gov.uk. Zimmern's paper is not available with the rest of the presentations from the seminar. I take full responsibility for any errors in paraphrasing.
} 
rule is transparent if 'words with well-defined and universally accepted meanings are chosen' (Diver 1983 p 67). A rule is accessible to the target audience if it is 'applicable to concrete situations without excessive difficulty or effort' (Diver 1983 $\mathrm{p}$ 67). A rule is congruent if 'the substantive content of the message' as communicated by the draftsman 'produces the desired behaviour' (Diver 1983 p 67). In essence, a rule must be very tightly drafted so as to ensure ease of application, ease of interpretation, and therefore some success in achieving the desired purposes.

We have seen that in order to be transparent, rules must use words with welldefined and universally accepted meanings. The concept of fairness will certainly cause a problem. The Chambers 21 st Century Dictionary (undated) defines fairness as ' 1 just; not using dishonest methods or discrimination. 2 in accordance with the rules'. Although this definition seems to accord with what we mean by fairness, it does not help us at all in defining a concept of fairness for legislative purposes. Since legislation is intended to create the rules, it is of no help to us to say that fairness is 'in accordance with the rules'. This cannot help us to decide if the rules are fair. The first definition might help with that: the rules are fair if they are just. But, what do we mean by just? If we are interested in justice, then we might turn to historical ideas of justice based in vengeance. If it is important to us for people to pay for their actions and decisions, then we might choose to fine people in some way for behaviour that is considered inappropriate. If we were trying to create a life insurance system on this basis, then we might fine people for the decision to smoke, or for not exercising. It would require a clear definition of what we consider to be inappropriate behaviour and a scale of fines. This approach values the correct choices, and it is the choice that is crucial. Those who appear not to have made a choice would be exempt from the fine. Whilst this would protect sufferers of genetic conditions, since they would not have chosen to have the predisposition, it could be used to punish their parents. The notion of inappropriate behaviour might include embarking on intimate relationships where there is a high risk of passing on a genetic condition. People could be required to have genetic tests prior to marriage and prevented from marrying where there is a significant risk. Since it is also possible to have children outside of wedlock, this could be taken a step further, and procreation could be regulated in a way to prevent genetically inappropriate coupling. Although one might argue that this is extremely far-fetched, it began with a widely recognised historical concept of justice. It illustrates the importance of defining the starting point in a way which prevents it being used in a way which we do not intend.

If we are thinking about fairness in insurance then we might use actuarial fairness as the starting point. This approach requires each individual to be responsible for the risk that he brings to the insurance pool. Specifically, it is unfair to require other individuals to subsidise risks unrelated to them (Moultrie and Thomas 1997; Leigh 1998; Wood and Williams 1964; Joly et al 2003; Nowlan 2002). Therefore, on this view, insurers are entitled to set individual insurance premiums on whatever basis they choose. All information must be disclosed, and insurers may use it in whatever way they see fit. This would amount to an absolute freedom to underwrite, as envisaged by Leigh (1998) who argues that insurers must be able to use any information to distinguish between people whether it is relevant or irrelevant to the decision offered. His extreme conception would include the right to distinguish people on the grounds of race, an activity which the UK's Race Relations Act 
expressly prohibits. Whilst legislation based on this concept of fairness would satisfy insurers $^{12}$ it seems not to fulfil our ideas about the most just way to administer society. Further, it argues not that we should be trying to remove discrimination between people, but that we should embrace it and increase the divisions between individuals and groups in society. Rather than trying to remove or mitigate the disadvantages caused by genetic make-up, the solution is to disadvantage others on different grounds. Whilst this would seem to be one of the least satisfactory conceptions of fairness on which to base our legislation, it is ironic to note that it would be relatively easy to draft legal provisions to put it into effect.

A second conception of fairness which might be useful to us, is that proposed by John Rawls. He argues that there are two principles underpinning a just society: all individual members of society should be equal, and that the only occasion when they may be treated unequally is to improve the position of the worst off (Rawls 1999). He uses an extended metaphor, the original position, to explain how these principles would be arrived at. He argues that a group of rational and mutually disinterested persons (Rawls 1999 p 125) who are behind a veil of ignorance (Rawls 1999 p 118), in that they are not aware of the characteristics that they have, whether they are rich or poor, healthy or ill, male or female, would choose these two principles as the basis for a just society. The argument is that since the persons in this original position would not know whether they were to be the worst off members of the society they were designing, they would ensure that those who were worst off were appropriately protected. This concept of fairness runs exactly counter to the conception of actuarial fairness invoked by the insurance industry. It requires society to protect those who are disadvantaged by their position, and give them the opportunities that they might otherwise be denied. This is a much more satisfactory concept of fairness, which would seem to protect those disadvantaged by their genetic make-up, but without disadvantaging others.

Whilst this might amount to a satisfactory definition of fairness, it is far from a universally accepted meaning of fairness. In order to use this in legislative provisions, additional definitions must be included to ensure that adjudicators know what concept of fairness they were required to apply. In order to be transparent then, the legislating for fairness claim could be written in this way:

1) Individuals should act fairly in their dealings with one another.

2) Acting fairly requires individuals to treat each other equally except where equal treatment results in unequal outcomes.

3) If treating people equally results in a disadvantage to one party, then individuals are required to treat others differently in order to improve the position of the worst off.

Whilst we may have solved the transparency challenge, it would seem that the legislating for fairness claim would fail the accessibility requirement that it can be applied to a concrete set of circumstances without excessive difficulty or effort. Consider a concrete set of circumstances such as this: Edward has been refused life insurance coverage. The reason given by the insurer is his genetic predisposition

\footnotetext{
${ }^{12}$ It is worth noting that Spencer Leigh is somewhat of an extremist, and it is far from clear that all insurers would argue for a completely unfettered freedom to underwrite. However, it also seems unlikely that they would argue against it if it were handed to them on a plate.
} 
towards condition $\mathrm{X}$, a condition characterised by loss of mental function and motor function after the age of 70 . If the legislating for fairness claim is a requirement to act fairly towards each other, then it should be apparent that it will be extremely difficult to apply it to this set of concrete circumstances. Edward would argue that it is unfair to deny him life insurance in this case. The insurer would argue that it is unfair to require them to cover Edward's life. Both might argue that they are the worst off in this situation. Unless there is a schedule of additional considerations for an adjudicator to use, it would be extremely difficult to decide which party's interests should prevail. Furthermore, if this was adjudicated by a court in a common law country, that court would be forced to make a decision and to give reasons for that decision. A court would do the best they could, but would inevitably end up filling in the gaps for themselves. This leads to judge-made law, which can be difficult to apply in any general way, and is therefore likely to be inconsistently applied. This is problematic for the potential claimants, who have no way of predicting how the law will be applied to their situation.

To ensure accessibility, rules should anticipate the circumstances to which they will apply. Edward's circumstances involve denial of insurance and genetic make-up. When deciding how the law should apply to his situation, Edward should be able to look at laws relating to denial of insurance or rules relating to genetic make-up. Ideally, those rules would be sufficiently clearly written that he would be able to reach a conclusion about how they would apply to his own situation. However, there is a further balance to be made here. Whilst it is undesirable to have a rule which requires fairness between parties, it is perhaps equally undesirable to have rules that are too specific. This could lead to a glut of rules that will be used only rarely. It is unnecessary, for example, to have a rule which deals with denial of insurance on the basis of a predisposition towards condition X. If we think that it is unacceptable to deny insurance on the basis of a predisposition towards condition $\mathrm{X}$, then we may also think that it is unacceptable to deny insurance on the basis of a predisposition towards condition $\mathrm{Y}$, and condition $\mathrm{Z}$. Rather than write a series of different rules prohibiting the denial of insurance coverage on a number of different bases, it would be better to aim for a middle ground. A middle ground might look something like this:

1) It is prohibited to deny insurance coverage if the reason for doing so falls within section 2.

2) Prohibited reasons include: genetic predispositions, family history information, and current medical conditions...

This provision indicates how legislative rules should be constructed in order to be both accessible and transparent. It is the third requirement which will indicate how section 2 should be drafted.

A law will be congruent if it delivers the desired results. The question is then, what are the results that we desire? If what we are concerned about is the appropriate uses of genetic information, then that should be the basis of the legislative provision that is written. For example:

1) Genetic information can be used for the purposes set out in section 2 .

2) Appropriate purposes include: insurance underwriting, providing medical care, employment decisions... 
Alternatively, we could be concerned about discrimination in the insurance market. Legislative provisions addressing that issue could start from the premise that discrimination in the insurance context is prohibited. We would then need to be very clear about the types of discrimination that we consider to be inappropriate. When constructing legislative provisions, the primary focus must be on the policy that underpins that legislation. If the policy is sound - if we know what it is that we want our legislation to do - then drafting it will be relatively straightforward. If the policy is not clear, no amount of skilful drafting will make the legislation work.

\section{Conclusion}

The message to be drawn from this article is this: grounding arguments about the appropriate uses of genetic information in the claim of genetic exceptionalism is likely to generate more heat than light. Even if there is any truth to the claim that genetic information is special in some way, such truth is likely to get lost among the hyperbole of genes as the essence of humanity. Not only is the claim of genetic exceptionalism unlikely to carry much weight in legal challenges to legislation, the concept itself offers little guidance on the appropriate uses of genetic information, and where the boundary ought to be drawn between appropriate and inappropriate uses.

On the other hand, attempts to sidestep this question at the policy level by advocating legislation in terms of vague standards such as fairness are also likely to fail, due to their inadequate legislative precision. Suggestions to this effect demonstrate a fundamental lack of understanding both of the legislative process, and of the way in which judges discern legislative intent. In conclusion, it seems that there is no way of avoiding direct engagement with the often difficult policy questions concerning the appropriate uses of genetic information. In order to enact useful and effective legislation, we must tackle the policy questions head on. Anything less will always result in weak and ineffective legislation, legislation it would be better not to have had in the first place.

Acknowledgements The author would like to thank Lindsay Stirton, colleagues at the University of Sussex, Loane Skene and the two anonymous reviewers.

Open Access This article is distributed under the terms of the Creative Commons Attribution Noncommercial License which permits any noncommercial use, distribution, and reproduction in any medium, provided the original author(s) and source are credited.

\section{References}

Anonymous. President Bush signs Genetic Information Nondiscrimination Act into law. $2008<$ http:// www.sciencedaily.com/releases/2008/05/080526152654.htm> accessed 17 June 2009.

Ashcroft R. Should genetic information be disclosed to insurers-No. Br Med J. 2007;334:1197-7.

Association of British Insurers. Insurance genetics moratorium extended extended to 2014. $2008<\mathrm{http}: / /$ www.abi.org.uk/Newsreleases/viewNewsRelease.asp?nrid=16274> accessed 17 June 2009.

Chambers. undated <http://www.chambersharrap.co.uk/chambers/features/chref/chref.py/main?query= fairness\&title=21st\&sourceid=Mozilla-search $>$ accessed 21 February 2010.

Davey J. Future imperfect: Human genetics and insurance. J Bus L. 2000;Nov:587-617.

Daykin C, Akers D, MacDonald A, McGleenan T, Paul D, Turvey P. Genetics and insurance-some social policy issues. Br Actuar J. 2003;9:787-830. 
Department of Health. Association of British Insurers. Concordat and moratorium on genetics and insurance. $2005<$ http://www.dh.gov.uk/en/Publicationsandstatistics/Publications/PublicationsPolicy AndGuidance/DH 4105905> accessed 17 June 2009.

Diver C. The optimal precision of administrative rules. Yale L J. 1983;93:65-109.

Fink S. EEOC v BNSF: The risks and rewards of genetic exceptionalism. Washburn L J. 2003;42:525-34.

Genetics and Insurance Committee. Genetics and Insurance Committee undated <http://www.dh.gov.uk/ ab/GAIC/index.htm> accessed 25 May 2010.

Green M, Botkin J. Genetic exceptionalism in medicine: clarifying the differences between genetic and non-genetic tests. Ann Intern Med. 2003;138:571-5.

Holm S. Should genetic information be disclosed to insurers-Yes. Br Med J. 2007;334:1196-6.

Hudson K, Holohan M, Collins F. Keeping pace with the times - the genetic information nondiscrimination act 2008. N Engl J Med. 2008;358:2661-3.

Human Genetics Commission. Human Genetics Commission response to the Discrimination Law Review consultation, A Framework for Fairness: Proposals for a Single Equality Bill for Great Britain. $<$ http:// www.equalities.gov.uk/equality_bill/introduction.aspx> accessed 17 June 2009.

Joly Y, Knoppers B, Godard B. Genetic information and life insurance: a "real" risk? Eur J Hum Genet. 2003;11:561-4.

Kirby D. The new eugenics in cinema: Genetic determinism and gene therapy in GATTACA. Sci Fict Stud. 2000;27:193-215.

Leigh S. The freedom to underwrite. In: Sorrell T, editor. Health care, ethics and insurance. London: Routledge; 1998. p. 11-53.

Lowe, Z. Paul Hastings fights genetic discrimination claims under new law. Am Law Daily. $2010<$ http:// amlawdaily.typepad.com/amlawdaily/2010/05/genetic-discrimination.html> accessed 1 June 2010.

Macdonald A. Genetics and insurance. In: Teugels J, Sundt B, editors. Encyclopedia of actuarial science. Chichester: Wiley; 2004. p. 769-78.

Matloff E, Shappell H, Brierly K, Bernhardt B, McKinnon W, Peshkin B. What would you do? Specialists' perspectives on cancer genetic testing, prophylactic surgery and insurance discrimination. J Clin Oncol. 2000;18:2484-92.

Meyer R. Justification for permitting life insurers to continue to underwrite on the basis of genetic information and genetic test results. Suffolk U L Rev. 1993;27:1271-306.

Mitton L. Financial inclusion in the UK: review of policy and practice. York: Rowntree; 2008.

Moultrie T, Thomas R. The right to underwrite? An actuarial perspective with a difference. $1997<$ http:// www.guythomas.org.uk/pdf/rtu.pdf> accessed 11 June 2009.

Murphy T. Genetic anti-discrimination law starts Thursday. $2009<$ http://www.forbes.com/feeds/ap/2009/ 05/20/ap6448494.html> accessed 17 June 2009.

Nowlan W. A rational view of insurance and genetic discrimination. Sci. 2002;297:195-6.

Rawls J. A theory of justice. Revised ed. Oxford: OUP; 1999.

Richards M. How distinctive is genetic information. Stud Hist \& Phil of Bio \& Biomed Stud. 2001;32:663-87.

Sarata A. Genetic exceptionalism: Genetic information and public policy. Congressional Research Service Report for Congress; 2008.

Science and Technology Committee. Fifth report on genetics and insurance. HC 2000-1:174.

Smith R, Raithatha N. Why disclosure of genetic tests for health insurance should be voluntary. J Health Serv Res Policy. 2006;11:184-6.

Wilkinson, R. Unjustified discrimination: Is the moratorium on the use of genetic test results by insurers a contradiction in terms? Health Care Anal. 2010; doi:10.1007/s10728-009-0137-9.

Wood G, Williams C. High cash value life insurance policies and unfair discrimination. J Risk Insur. 1964;31:557-72. 